\title{
Investigation into Self-regulation, Engagement in Learning Mathematics and Science and Achievement among Bahrain Secondary School Students
}

\author{
Masooma Ali Al Mutawaha, Ruby Thomas ${ }^{a}$ and Myint Swe Khine ${ }^{b}$ \\ aUniversity of Bahrain, KINGDOM OF BAHRAIN; 'bmirates College for Advanced Education, \\ UNITED ARAB EMIRATES \\ Students' view on themselves is the root of self-regulatory skills, and it will serve as an evaluator of \\ their capability to succeed. This study attempts to find the relationship between students' self- \\ regulation in learning and academic achievements in Mathematics and Science in the secondary \\ schools in Bahrain. 'Engagement in Mathematics/Science Learning and Self-Regulation' \\ questionnaires adopted from TIMSS (2011) and administered to different sets of students. The data \\ was analyzed to explore the reliability of the questionnaires and the association between self- \\ regulation and academic achievement. The study found that there is a positive correlation between \\ them in both cases.
}

KEYWORDS

Self-regulation, Engagement, Academic achievement and

Reliability.
ARTICLE HISTORY

Received 15 May 2017

Revised 10 July 2017 Accepted 10 September 2017

\section{Introduction}

Self-regulation (or self-regulated learning) refers to learning that results from students' self-generated thoughts and behaviors that are systematically oriented in order to attain their learning goals. Self-regulated learning involves goal-directed activities that students instigate, modify, and sustain (Zimmerman, 1994, 1998). Current researches interpret students are active information seekers and processors. Learners' cognitions can influence the instigation, direction, and persistence of achievement behaviors (Bandura, 1997; 
Schunk, 1995; Zimmerman, 1998). Although many studies in recent years have clearly revealed how self-regulatory processes lead to success in school, only few teachers currently prepare students to learn on their own (Zimmerman; 2002). Thomas Jefferson as cited by Soutter and Seider (2013), stated that "Character education played an integral role in the original vision of both K-12 and postsecondary education in the United States. At the K-12 level, Thomas Jefferson cited the development of children's character as a key motivation for the establishment of public schools in the United States" (McClellan, 1999). Pajares (2002; p117) stated that "The beliefs students develop about their academic capabilities help to determine what they do with their learning, their academic performances are the result of what they come to believe they can accomplish'. While Zimmerman (2002; p. 65) stated that 'Self-regulation is not a mental ability or an academic performance skill; rather it is the self-directive process by which learners transform their mental abilities into academic skills'. The students with better self-regulation skills typically learn more with less effort and report higher levels of academic satisfaction (Pintrich, 2000; Zimmerman, 2000). Hannula (2004; p.114) stated "There is a relationship between students' self-concept, self-esteem, self-confidence and anxiety, and further the qualities of their motivational or learning outcomes, which is often negative and inhibiting in nature, resulting in disturbance of students' mathematics learning, problem solving, or performances". He also mentioned that "the qualities and functioning of significant self-system processes ultimately determine the power and role of affect in students' personal learning or performance processes in mathematical situations'(p.115). Velayutham et al (2011; p. 2159) stated 'An important aim of science education is to empower students by nurturing the belief that they can succeed in science learning and to cultivate the adaptive learning strategies required to help to bring about that success'.

Self-regulation has been shown to be important for academic achievement (e.g., Zimmerman \& Martinez-Pons, 1986, 1988). In mathematics specifically, self-regulation has been linked with academic performance (Nota, Soresi, \& Zimmerman, 2004) since it impacts actual study processes (Schoenfeld, 1992) that involves goal setting, commitment, efforts, and persistence (Corno, 2001; Gollwitzer, \& Brandstätter, 1997; Kuhl \& Fuhrmann, 1998) throughout a management of study progress (Schoenfeld, 1987). Researchers suggest that one way of promoting the acquisition of knowledge and skills is to help students regulate their learning; that is, to become more metacognitively, motivationally, and behaviorally responsible for their own learning (Boekaerts 1996; Zimmerman 1995, 2000, 2002). According to theoretical approaches (cf. Winne 2000; Zimmerman 2000), the use of self-regulation results in an improved performance. Experimental studies have proven the strong link between the capacity to self-regulate one's learning and self-efficacy (Zimmerman and Kitsantas 2005, 2007), intrinsic task interest (Schunk 1986, 1996; Zimmerman 1995), and academic achievement (e.g., Pintrich and De Groot 1990; Zimmerman and Martinez-Pons 1986, 1988). Thus, the goal to enhance academic achievement might be accomplished through increasing students' selfregulation.

This bring light towards the fact that self-regulation is the key to succeed in learning Mathematics and Science, and was the reason for conducting this 
study among the students in Bahrain schools. Mathematics and science are believed to be the most difficult subjects at school level. Findings from this study will be a very helpful tool for teachers, curriculum developers and parents to understand the importance of developing self-regulation learning habits in mathematics and science education to help students to become life-long learners by improving their quality of learning and performance and hence competence and skill development as part of the educational reform.

\section{Literature Review}

Self-regulated learning refers to one's ability to understand and control one's learning environment. To self-regulate means "to change ... oneself, or some aspect of oneself, so as to conform to some idea or concept" (Forgas, Baumeister, \& Tice, 2009, p. 4). Self-regulation abilities include goal setting, self-monitoring, self-instruction, and self-reinforcement (Harris \& Graham, 1999; Schraw, Crippen, \& Hartley, 2006; Shunk, 1996). Self-regulation can help students create better learning habits and strengthen their study skills (Wolters, 2011), apply learning strategies to enhance academic outcomes (Harris, Friedlander, Sadler, Frizzelle, \& Graham, 2005), monitor their performance (Harris et al., 2005), and evaluate their academic progress (De Bruin, Thiede \& Camp, 2011). Self-regulated learners also manipulate their learning environments to meet their needs (Kolovelonis, Goudas, \& Dermitzaki, 2011). Moreover, researchers found that self-regulated learners are more likely to seek out advice (Clarebout et al., 2010) and information (De Bruin et al., 2011) and pursue positive learning climates (Labuhn et al., 2010). In a study of high school students, Labuhn et al. (2010) found that learners who were taught self-regulated learning skills through monitoring and imitation were more likely to elicit higher levels of academic self-efficacy and perform higher on measures of academic achievement compared to students who did not receive selfregulated learning instruction.

There are various models of self-regulated learning developed in recent researches. Educational psychologist Paul Pintrich concluded conceptualization of self-regulated learning as one aspect of self-regulation, This processes mediate between personal and environmental characteristics and achievement (Pintrich \& DeGroot, 1990). Pintrich's model of self-regulated learning identified metacognition, strategic action and motivation to learn as critical dimensions (Butler \& Winne, 1995; Boekerts \& Corno, 2005). Self-regulation of learning takes place if students direct their own learning (Boekaerts, \& Corno 2005). Selfregulation is accepted to involve processes that allow individuals to exert control over their houghts, feelings, and actions (Baumeister \& Vohs, 2004). It enables individuals to adapt to their social and hysical environment, and is, therefore, a key process in psychological functioning (Schmeichel \& Baumeister, 2006). Learning is important for performance enhancement, but learning can also play a role in enhancing levels of physical activity. Following the self-enhancement hypothesis, human beings intend to maximize positive feelings or effectively master challenging tasks (e.g., Deci \& Ryan, 2002; Fox \& Wilson, 2008; Nicholls, 1989). Self-regulation of learning can contribute to individuals' perceived competence and expectations for success by increasing their ability in a more effective manner (e.g: Zimmerman, 2006).

Eilam et al (2009) did an explorative field study to examine the 
relationship between the personality trait and science achievement. They conducted their study on a sample of 52 grade eight students, and collected data of personality traits, self-reported study strategies and science project achievement. The study findings showed significant relationships between conscientiousness and achievement. Velayutham et al (2012) investigated the influence of students' motivational beliefs in science learning on students' selfregulation in the science classroom. Data were collected from 719 boys and 641 girls across grades 8-10 in 5 public schools in Perth, Australia. Results from structural equation modeling analysis indicated that all 3 motivational constructs were strong predictors of students' self-regulation in science learning. Sparkman et al (2002) were pointing out that success in university level may relate to non-cognitive variables. In their study they found that emotional intelligence have potential effects on student's ability to persist and graduate from university. Also Strayhorn (2015) did a research to explore the factors which can affect undergraduate students' interest, readiness and success in math and science learning and preparation for STEM careers. His study results showed that self-efficacy and sense of belonging were relevance and significance factors of students' academic success. Finally he highlighted the importance of future policy, practice, and research. Also teachers should encourage the students maintain their grit not only to be successful in their future careers, but also to be creative. Davis (2011) found that the non-cognitive factors like personality and motivation to learning correlate with creativity. Also Khalil (2008) found that the non-cognitive factors play a significant role in earning a degree.

Learning is considered to be multisource in nature (Iran-Nejad et al., 1990), and factors influencing students' learning process must be examined. One such factor is the students' ability to self-regulate their learning. Also, students' self-regulated behavior might be affected by their beliefs about knowledge in general and mathematics in particular (Crawford et al., 1998; Hofer, 1999; Paulsen \& Feldman, 2007). Students' achievement depends on their study habits. Self-regulated study habits are very much essential for in learning mathematics and science as this is the time they develop their interest in the subject and conceptualize their knowledge. A large body of research from the United States examines the relationship between self-regulation and academic achievement. These studies have demonstrated that in the preschool year, selfregulation is associated as much with mathematics as with literacy (e.g., Becker,McClelland, Loprinzi, \& Trost, 2014; McClelland et al., 2007).The need for self-regulation is apparent in mathematics, especially in developmental mathematics courses (Kinney, 2001). In its vision statement, Principles and Standards for School Mathematics, the National Council for Teachers of Mathematics (NCTM, 2000) advocates the active participation of students in mathematical learning activities designed to deepen their conceptual understanding of mathematics by actively making connections between new concepts and prior knowledge, as well as between mathematical concepts and real-world applications. The use of various learning strategies has been shown to promote mathematics achievement on the upper elementary level (Eshel \& Kohavi, 2003), the secondary level (Pokay \& Blumenfeld, 1990), and the university level (Pape \& Smith, 2002). There is relationships between selfregulated learning strategies and motivational beliefs in different grades and different lessons and self-regulated learning strategies improved skills (Canca, 
2005; Ergöz, 2008; Garavalia \& Gredler, 2002; Glaser \& Brunstein, 2007; Haşlaman, 2005; Kitsansas, Sten \& Huie, 2009; Ruban \& Reis, 2006; Zimmerman, Bandura \& Martinez-Pons, 1992). However in one study, rehearsal learning strategies had a negative effect on mathematics achievement (Koller, 2001). Middle school students' belief in the usefulness of mathematics was a statistically significant positive predictor of problem-solving scores and GPA (Schommer-Aikins, Duell, \& Hutter, 2005). Cantwell (1998) found that high selfregulation skills correlated positively with academic success; conversely, low self-regulation skills correlated with low academic success. A study by Nota et al. (2004) found that self-regulation predicted academic success. Numerous research studies have reported that using self-regulation strategies at almost all stages of education positively affects academic performance (Bembenutty \& Zimmerman, 2003; Cantwell, 1998; Eom \& Reiser, 2000; Nota, Soresi, \& Zimmerman, 2004; Pintrich \& De Groot, 1990; Trainin \& Swanson, 2005; Uredi \& Uredi, 2005).

An individual's mathematical beliefs have been classified into three categories: beliefs about mathematics education, beliefs about the self in relation to mathematics, and beliefs about the social context (De Corte et al., 2002). A review of multiple studies on student mathematical beliefs revealed that, in general students hold immature beliefs about mathematics and the learning of mathematics (Muis, 2004). A traditionally accepted view of mathematics held by students is that mathematical knowledge is a collection of unrelated facts and procedures (Grouws, Howald, \& Colangelo, 1996; Schoenfeld, 1992). Students believe that doing mathematics is to obey the rules and that knowing mathematics is to recall the appropriate rule (Lampert, 1990). They assume that only one correct method to solve a problem exists, which is used to obtain the one and only correct answer (Schoenfeld, 1992). Many students believe that mathematics is learned by memorization (Kenney \& Silver, 1997; Schoenfeld, 1989). These are conflicting with the conceptualization of mathematics and mathematics learning supported by the NCTM Principles and Standards, which emphasizes conceptual understanding rather than memorization. Because mathematical beliefs are assumed to influence how students engage in mathematical behavior, they might affect students' levels of mathematics achievement (Schoenfeld, 1992). Previous studies have shown that selfregulation skills have a positive association with academic achievement independent of children's intelligence (Bull \& Scerif 2001; Valiente et al. 2008; Zhou et al. 2010; Moffitt et al. 2011). Uredi and Uredi (2005) reported that selfregulation strategies and motivational beliefs could predict success in mathematics. Bembenutty and Zimmerman (2003) emphasized a causal relationship between self-regulation and academic achievement. All these studies lead to the conclusion that if the students who have high self-regulation skills can control their learning behaviors and if they can re-regulate these behaviors according to different learning situations, their academic performances are affected positively. Mathematics is no longer mainly conceived as a collection of abstract concepts and procedural skills to be mastered, but primarily as a set of human sense-making and problem-solving activities based on mathematical modeling of reality (De Corte, Verschaffel, \& Op'teynde, 2000, p. 687). From this point of view, student's use of various cognitive and metacognitive strategies to regulate on their own cognition, behavior and motivation in self-regulated learning might be appropriate for the conceptual 
understanding of mathematics and science and building an insight and making sense of the concept.

This research analyses the correlation between students' goal orientation, task value, self-efficacy, self-regulation and their achievement in mathematics and science, which are mainly identified as motivational components. Goal orientation validates their reasons for why they have engaged in a task. Task value items covers students' beliefs in their evaluation on how interesting, how important and how useful a task is. Goal orientation can be defined as individuals' goals when approaching, engaging in and responding to achievement situations. Goal theorists describe two types of goal orientationnamely, mastery goals and performance goals (Zusho et al., 2003). Greater task value guarantees more participation in the learning process. Self-efficacy of learning questions contains learners' beliefs for success and for self-efficacy. Their belief on success includes performance based which is related to task performance. Expectancy for success includes mostly performance-based expectancy and it is related especially to task performance. Expectancy for selfefficacy is the self-appraisal of ability to perform a task (Pintrich, Smith, Garcia \& McKeachie, 1991).

\section{Research Aims}

This study aims to determine the following:

The reliability of the two translated questionnaires when administered to the secondary school students in Bahrain.

The relationships between students' self-regulation and engagement in learning mathematics and academic achievements.

The relationships between students' self-regulation and engagement in learning science and academic achievements.

\section{Hypothesis}

The hypotheses of this research are:

Students' self-regulation and engagement will be a positive indicator of students' achievement in mathematics.

Students' self-regulation and engagement will be a positive indicator of students' achievement in science.

\section{Research Method}

This study used two questionnaires to measure the level of students' selfregulation and engagement and their achievement in mathematics and science. A total of 759 students from secondary schools (grade 9 to 12) in Bahrain participated in the study. The details are as shown in table 1.

Their midterm exam grade represented their academic achievement that they have achieved at the same semester just beforehand completion of the questionnaire.

Engagement in Mathematics Learning and Self-Regulation (32 Items) questionnaire was adopted from TIMSS (2011), and translated into Arabic.

Engagement in Science Learning and Self-Regulation (32 Items) 
questionnaire was adapted from TIMSS (2011), and translated into Arabic.

The

website

of

TIMSS

2011

(https://timssandpirls.bc.edu/timss2011/index.html) states that it is the fifth in international assessments of student achievement dedicated to improving teaching and learning in mathematics and science. TIMSS conducts comprehensive state-of the-art assessments of student achievement supported with extensive data about country, school, and classroom learning environments. TIMSS participants share the conviction that comparing education systems in terms of their organization, curricula, and instructional practices in relation to their corresponding student achievement provides information crucial for effective education policy-making. Both questionnaires are on a five-point Likert-type scale containing thirty two items which are categorized in four groups such as learning goal orientation, task value, self-efficacy and selfregulation. Under learning goal orientation there are eight items (questions 1 to 8) which give an idea of students' goal setting and recognizing the significance of grasping the concepts discussed in the classroom in order to get a better understanding of the subject matter. Under task value, the eight items (questions 9 to 16) draw light towards the importance of the task which the students are assigned in the learning process. The students assess the mathematics and science tasks which are given to them on a five-point Likert type scale. The next eight items (questions 17 to 24) give information on students' self-efficacy. This shows how efficient and hardworking they are. Whether they understand the content that is taught in the class and through hard work they obtain good grades in both mathematics and science. The items numbered 25 to 32 are categorized under self-regulation. This is to measure how motivated they are in learning in school or after school. It clearly checks whether they are concentrating in the class while teaching and they give up tasks easily or not. It also checks the extent to which they work on the assignments and other tasks to complete them on time.

\section{Process}

The instruments are administered to different sets of government secondary school students in the Kingdom of Bahrain in the first semester of the academic year 2016-17 with the permission of the school authorities and collected the results.

\section{Data Analysis}

The data was analyzed using SPSS. Descriptive analysis on items in each questionnaire and reliabilities of each questionnaire were performed and the following section reports the results.

\section{Results}

The data obtained in this research were analyzed by using descriptive statistics (mean, standard deviation, skewness, and kurtosis). The results were used to explore the students' profiles about achievement in Mathematics and science and self-regulated learning skills. Mean, standard deviations, and correlations among task value, control of learning beliefs, goal orientation, selfefficacy, and achievement in Mathematics and Science are described in tabular form. On examining the correlations between the variables in the research, it was found that all the variables possess a positive and significant correlation 
between them.

Table 1: Distribution of students in each grade

\begin{tabular}{|l|c|c|c|c|c|c|}
\hline \multirow{2}{*}{ Grade } & \multicolumn{2}{|c|}{ Math } & \multicolumn{2}{c|}{ Science } & \multicolumn{2}{c|}{ Total } \\
\cline { 2 - 7 } & & & & & & \\
& Freq. & $\%$ & Freq. & $\%$ & Freq. & $\%$ \\
\hline 9 & 110 & 29.2 & 105 & 27.5 & 215 & 28.3 \\
\hline 10 & 103 & 27.3 & 87 & 22.8 & 190 & 25.0 \\
\hline 11 & 83 & 22.0 & 90 & 23.6 & 173 & 22.8 \\
\hline 12 & 81 & 21.5 & 100 & 26.2 & 181 & 23.8 \\
\hline Total & 377 & 100.0 & 382 & 100.0 & 759 & 100.0 \\
\hline
\end{tabular}

It is evident from the table that almost same percentages of participants are included over various grade levels.

Table 2: Reliability of attitudes toward mathematics questionnaire (Engagement in Mathematics Learning and Self-Regulation items) scale scores descriptive statistics

\begin{tabular}{|l|c|c|}
\hline \multicolumn{1}{|c|}{ Scale } & Number of items & Alpha \\
\hline Learning goal orientation & 8 & 0.835 \\
\hline Task value & 8 & 0.915 \\
\hline Self-efficacy & 8 & 0.905 \\
\hline Self-regulation & 8 & 0.856 \\
\hline Overall & 32 & 0.931 \\
\hline
\end{tabular}

According to the above table, the reliability measures of learning goal orientation, task value, self-efficacy and self-regulation are very evident. The reliability coefficient (alpha) can vary from 01 to 1 with 0 representing complete error and 1 representing a total absence of error. The values in the table indicate a high level of internal consistency, accuracy and reliability of the questionnaire, Engagement in Mathematics Learning and Self-Regulation items. This means that the instrument which we used in this study is highly reliable. 
Table 3: Attitudes toward mathematics questionnaire (Engagement in Mathematics Learning and Self-Regulation items) scale scores descriptive statistics

\begin{tabular}{|l|c|c|c|c|}
\hline Scale & Minimum & Maximum & Mean & SD \\
\hline $\begin{array}{l}\text { Learning goal orientation (8 items, from 1- } \\
\text { 8) }\end{array}$ & 17 & 40 & 33.85 & 5.15 \\
\hline Task value (8 items, from 9-16) & 8 & 40 & 28.93 & 7.72 \\
\hline Self-efficacy (8 items, from 17-24) & 11 & 40 & 33.12 & 6.28 \\
\hline Self-regulation (8 items, items 25-32) & 9 & 40 & 31.62 & 5.91 \\
\hline
\end{tabular}

Attitude towards Mathematics was measured using four subscales that are learning goal, task value, self-efficacy and self-regulation. The questionnaire contained 32 items. The responses were scored using a 5-point Likert scale. Out of 40 task value items and self-regulation items scored very less, eight and 9. The standard deviation shows a higher variation in task value items. It means most of the students do not value the tasks which are assigned to them in Mathematics. They are less hard working and not seem to be self-motivated. Table 3 shows that the means of the sample responses to the instrument are 33.85 for learning goal orientation items, 28.93 for Task value items, 33.12 for Self-efficacy items, and 31.62 for Self-regulation items. The learning goal orientation and self-efficacy have almost same value for their averages. The selfregulation items are the next and the least is for the task value items.

Table 4: Descriptive statistics of Engagement in Mathematics Learning and SelfRegulation (32 Items)

\begin{tabular}{|l|l|c|c|c|c|}
\hline No. & \multicolumn{1}{|c|}{ Item } & Mean & SD & Skew & Kurtosis \\
\hline 1 & One of my goals is to learn as much as I can. & 4.45 & 0.80 & -1.50 & 1.91 \\
\hline 2 & One of my goals is to learn new mathematics contents. & 3.65 & 1.17 & -0.66 & -0.25 \\
\hline 3 & One of my goals is to master new mathematics skills. & 3.87 & 1.13 & -0.87 & 0.08 \\
\hline 4 & $\begin{array}{l}\text { It is important that I understand my work. } \\
5\end{array}$ & 4.66 & 0.63 & -2.30 & 6.97 \\
\hline 6 & $\begin{array}{l}\text { It is important for me to learn the mathematics content that is } \\
\text { It is important to me that I improve my mathematics skills. }\end{array}$ & 4.14 & 0.98 & -1.19 & 1.29 \\
\hline 7 & It is important that I understand what is being taught to me. & 4.57 & 0.76 & -2.00 & 4.31 \\
\hline 8 & Understanding mathematics ideas is important to me. & 4.20 & 1.01 & -1.32 & 1.34 \\
\hline 9 & What I learn can be used in my daily life. & 3.43 & 1.24 & -0.51 & -0.67 \\
\hline
\end{tabular}




\begin{tabular}{|c|c|c|c|c|c|}
\hline 10 & What I learn is interesting. & 3.41 & 1.33 & -0.46 & -0.91 \\
\hline 11 & What I learn is useful for me to know. & 3.75 & 1.23 & -0.87 & -0.16 \\
\hline 12 & What I learn is helpful to me. & 3.79 & 1.22 & -0.88 & -0.08 \\
\hline 13 & What I learn is relevant to me. & 3.25 & 1.21 & -0.35 & -0.66 \\
\hline 14 & What I learn is of practical value. & 3.74 & 1.15 & -0.73 & -0.20 \\
\hline 15 & What I learn satisfies my curiosity. & 3.53 & 1.21 & -0.45 & -0.71 \\
\hline 16 & What I learn encourages me to think. & 4.02 & 1.13 & -1.15 & 0.61 \\
\hline 17 & I can master the skills that are taught. & 3.98 & 1.10 & -1.04 & 0.59 \\
\hline 18 & I can figure out how to do difficult work. & 3.92 & 1.08 & -0.97 & 0.48 \\
\hline 19 & Even if the mathematics work is hard, I can learn it. & 4.11 & 1.03 & -1.09 & 0.62 \\
\hline 20 & I can complete difficult work if I try. & 4.34 & 0.86 & -1.36 & 1.85 \\
\hline 21 & I will receive good grades. & 4.37 & 0.89 & -1.59 & 2.49 \\
\hline 22 & I can learn the work we do. & 4.31 & 0.89 & -1.44 & 2.05 \\
\hline 23 & I can understand the contents taught. & 4.13 & 1.04 & -1.21 & 1.03 \\
\hline 24 & I am good at mathematics. & 3.95 & 1.17 & -1.07 & 0.39 \\
\hline 25 & Even when tasks are uninteresting, I keep working. & 3.81 & 1.12 & -0.83 & 0.09 \\
\hline 26 & I work hard even if I do not like what I am doing. & 3.79 & 1.14 & -0.80 & -0.11 \\
\hline 27 & I continue working even if there are better things to do. & 3.56 & 1.15 & -0.52 & -0.45 \\
\hline 28 & I concentrate so that I won't miss important points. & 4.20 & 0.99 & -1.27 & 1.13 \\
\hline 29 & I finish my work and assignments on time. & 3.83 & 1.05 & -0.80 & 0.21 \\
\hline 30 & I don't give up even when the work is difficult. & 4.02 & 1.03 & -0.88 & 0.22 \\
\hline 31 & I concentrate in class. & 4.13 & 0.96 & -1.09 & 0.84 \\
\hline 32 & I keep working until I finish what I am supposed to do. & 4.27 & 0.91 & -1.16 & 0.87 \\
\hline
\end{tabular}

Table 4 shows that the means of the sample responses to the instrument are between (4.66) and (3.25) for the Engagement in Mathematics Learning and Self-Regulation items. This means that the participants strongly agree on the items. It is clear from the arithmetic means that the items that have higher means are those about the learning goals and their attitude in learning. Those students with learning goal as learning as much as they can, shows increasing desire in understanding whatever they are learning. Moreover, they give 
importance to it and seeming determined. They are ready to keep working until they accomplish their goals. Hence they are successful in their task and they get good grades. So students' achievement is highly correlated to goal setting and attains deeper understanding in mathematics concepts. This in turn leads to self-efficacy because their goal orientation is performance targeted. Specifically, students with high self-efficacy beliefs tend to set more challenging goals and make stronger commitment to accomplish these goals compared to students with low self-efficacy beliefs (Schunk, 2000). When facing difficulties students with higher self-efficacy will try to put more effort where as people with less selfefficacy will try to avoid those mathematical tasks. Thus learning goal setting and self-efficacy significantly affect academic achievement.

\section{Correlations among Engagement in Mathematics Learning and Self- Regulation and academic achievement (Exam)}

Table 5: Correlations between Engagement in Mathematics Learning and SelfRegulation and exam results

\begin{tabular}{|l|c|c|c|c|c|}
\hline & Exam & $\begin{array}{c}\text { Learning } \\
\text { goal } \\
\text { orientation }\end{array}$ & Task value & Self-efficacy & $\begin{array}{c}\text { Self- } \\
\text { regulation }\end{array}$ \\
\hline Exam & & $0.380^{* *}$ & $0.229^{* *}$ & $0.470^{* *}$ & $0.274^{* *}$ \\
\hline Learning goal & & & $0.662^{* *}$ & $0.669^{* *}$ & $0.586^{* *}$ \\
\hline orientation & & & & & \\
\hline Task value & & & & $0.611^{* *}$ & $0.499^{* * *}$ \\
\hline Self-efficacy & & & & & $0.665^{* *}$ \\
\hline
\end{tabular}

$* * \mathrm{p}<0.01$

Table 5 shows that the self-regulation has trivial positive correlation with achievement in Mathematics. But there is moderately higher positive correlation with learning goal orientation, task value and self-efficacy than self-regulation. Positive correlation indicates that the academic achievement depends on all the other variables. The correlation coefficients obtained are statistically significant as $p<0.01$. Academic achievement in Mathematics is directly depending on all these factors. Students who set their goal and working hard to chase the goal will be keeping themselves motivated and become high achievers. They find importance in the tasks which are assigned to them and try to finish them on time. 


\section{Engagement in Science Learning and Self-Regulation}

Table 6: Reliability of attitudes toward science questionnaire (Engagement in Science Learning and Self-Regulation items) scale scores descriptive statistics

\begin{tabular}{|l|c|c|}
\hline \multicolumn{1}{|c|}{ Scale } & Number of items & Alpha \\
\hline Learning goal orientation & 8 & 0.869 \\
\hline Task value & 8 & 0.910 \\
\hline Self-efficacy & 8 & 0.859 \\
\hline Self-regulation & 8 & 0.819 \\
\hline Overall & 32 & 0.905 \\
\hline
\end{tabular}

The reliability measures of learning goal orientation, task value, selfefficacy and self-regulation are presented in the table. These values indicate a high level of internal consistency and reliability of the questionnaire, Engagement in learning Science and Self-Regulation items. The reliability coefficient (alpha) can vary from 01 to 1 with 0 representing complete error and 1 representing a total absence of error. According to the above table, the reliability measures of learning goal orientation, task value, self-efficacy and self-regulation are very evident. Hence the instrument which we used in this study is highly reliable.

Table 7: Attitudes toward science questionnaire (Engagement in Science Learning and Self-Regulation items) scale scores descriptive statistics

\begin{tabular}{|l|c|c|c|c|}
\hline \multicolumn{1}{|c|}{ Scale } & Minimum & Maximum & Mean & SD \\
\hline Learning goal orientation (8 items, from 1-8) & 14 & 40 & 34.64 & 5.11 \\
\hline Task value (8 items, from 9-16) & 8 & 40 & 31.22 & 6.68 \\
\hline Self-efficacy (8 items, from 17-24) & 13 & 40 & 34.16 & 5.06 \\
\hline Self-regulation (8 items, items 25-32) & 14 & 40 & 32.10 & 5.30 \\
\hline
\end{tabular}

Attitude towards science was measured using four subscales that are learning goal, task value, self-efficacy and self-regulation. The questionnaire contained 32 items. The responses were scored using a 5-point Likert scale. Out of 40 task value items scored very less, only eight. It means most of the students do not value the tasks which are assigned to them in Science. They are hardworking and seem to be self-motivated. Table 7 shows that the means of the sample responses to the instrument are 34.64 for learning goal orientation items, 31.22 for Task value items, 34.16 for Self-efficacy items, and 32.10 for Self-regulation items. The learning goal orientation and self-efficacy have almost same value for their averages. The self-regulation items are the next and the least is for the task value items. The standard deviation shows a higher variation in task value items. 
Table 8: Descriptive statistics of Engagement in Science Learning and SelfRegulation (32 Items)

\begin{tabular}{|c|c|c|c|c|c|}
\hline No. & Item & Mean & SD & Skew & Kurtosis \\
\hline 1 & One of my goals is to learn as much as I can. & 4.49 & 0.75 & -1.79 & 4.18 \\
\hline 2 & One of my goals is to learn new science contents. & 3.99 & 1.04 & -1.02 & 0.71 \\
\hline 3 & One of my goals is to master new science skills. & 4.08 & 1.02 & -1.06 & 0.74 \\
\hline 4 & It is important that I understand my work. & 4.68 & 0.63 & -2.10 & 4.27 \\
\hline 5 & $\begin{array}{l}\text { It is important for me to learn the science content that is } \\
\text { taught. }\end{array}$ & 4.24 & 0.93 & -1.29 & 1.42 \\
\hline 6 & It is important to me that I improve my science skills. & 4.39 & 0.88 & -1.64 & 2.63 \\
\hline 7 & $\begin{array}{l}\text { It is important that I understand what is being taught to } \\
\text { me. }\end{array}$ & 4.54 & 0.79 & -2.22 & 5.90 \\
\hline 8 & Understanding science ideas is important to me. & 4.29 & 0.95 & -1.54 & 2.35 \\
\hline 9 & What I learn can be used in my daily life. & 3.91 & 1.04 & -0.86 & 0.37 \\
\hline 10 & What I learn is interesting. & 3.77 & 1.21 & -0.80 & -0.18 \\
\hline 11 & What I learn is useful for me to know. & 4.06 & 1.04 & -1.05 & 0.64 \\
\hline 12 & What I learn is helpful to me. & 4.09 & 1.06 & -1.19 & 0.82 \\
\hline 13 & What I learn is relevant to me. & 3.56 & 1.09 & -0.40 & -0.38 \\
\hline 14 & What I learn is of practical value. & 3.99 & 1.00 & -1.02 & 0.85 \\
\hline 15 & What I learn satisfies my curiosity. & 3.74 & 1.09 & -0.74 & 0.03 \\
\hline 16 & What I learn encourages me to think. & 4.12 & 0.99 & -1.14 & 0.95 \\
\hline 17 & I can master the skills that are taught. & 4.16 & 0.92 & -0.95 & 0.33 \\
\hline 18 & I can figure out how to do difficult work. & 4.13 & 0.84 & -0.85 & 0.53 \\
\hline 19 & Even if the science work is hard, I can learn it. & 4.28 & 0.96 & -1.53 & 2.23 \\
\hline 20 & I can complete difficult work if I try. & 4.41 & 0.79 & -1.45 & 2.37 \\
\hline 21 & I will receive good grades. & 4.44 & 0.84 & -1.77 & 3.35 \\
\hline 22 & I can learn the work we do. & 4.42 & 0.80 & -1.58 & 2.97 \\
\hline 23 & I can understand the contents taught. & 4.26 & 0.87 & -1.20 & 1.44 \\
\hline
\end{tabular}




\begin{tabular}{|l|l|c|c|c|c|}
\cline { 5 - 6 } 24 & I am good at science. & 4.07 & 1.07 & -1.16 & 0.80 \\
\hline 25 & Even when tasks are uninteresting, I keep working. & 3.79 & 1.08 & -0.75 & 0.07 \\
\hline 26 & I work hard even if I do not like what I am doing. & 3.91 & 1.05 & -0.72 & -0.11 \\
\hline 27 & I continue working even if there are better things to do. & 3.77 & 1.08 & -0.70 & -0.14 \\
\hline 28 & I concentrate so that I won't miss important points. & 4.19 & 0.91 & -1.08 & 0.79 \\
\hline 29 & I finish my work and assignments on time. & 3.92 & 1.04 & -0.86 & 0.14 \\
\hline 30 & I don't give up even when the work is difficult. & 4.12 & 0.97 & -0.87 & 0.07 \\
\hline 31 & I concentrate in class. & 4.16 & 0.89 & -0.94 & 0.50 \\
\hline 32 & I keep working until I finish what I am supposed to do. & 4.29 & 0.91 & -1.49 & 2.28 \\
\hline
\end{tabular}

Table 8 shows that the means of the sample responses to the instrument are between (4.68) and (3.56) for the Engagement in Science Learning and SelfRegulation items which means that the participants strongly agree on the items. It is clear from the means that the items that have higher means are those about the learning goals and their attitude in learning. Those students with learning goal as learning as much as they can, shows increasing desire in understanding whatever they are learning. They consider science as an important subject. Moreover, they give importance to it and seeming determined. They are ready to keep working until they accomplish their goals. Hence they are successful in their task and they get good grades. So students' achievement is highly correlated to goal setting and attains deeper understanding in science concepts. This in turn leads to self-efficacy. When facing difficulties students with higher self-efficacy will try to put more effort where as people with less self-efficacy will try to avoid those tasks. Thus learning goal setting and self-efficacy significantly affect academic achievement.

\section{Correlations among Engagement in Science Learning and Self- Regulation and academic achievement (Exam)}

Table 9: Correlations between Engagement in Science Learning and SelfRegulation and exam results

\begin{tabular}{|l|l|c|c|c|c|}
\hline & Exam & $\begin{array}{c}\text { Learning Goal } \\
\text { Orientation }\end{array}$ & Task value & Self-efficacy & $\begin{array}{c}\text { Self- } \\
\text { Regulation }\end{array}$ \\
\hline Exam & & $0.235^{* *}$ & $0.187^{* *}$ & $0.369^{* *}$ & $0.140^{* *}$ \\
\hline $\begin{array}{l}\text { Learning goal } \\
\text { Orientation }\end{array}$ & & & $0.633^{* *}$ & $0.584^{* *}$ & $0.441^{* *}$ \\
\hline Task value & & & & $0.609^{* *}$ & $0.379^{* *}$ \\
\hline Self-efficacy & & & & & $0.522^{* *}$ \\
\hline
\end{tabular}

$* * p<0.01$ 
Table 9 shows that the self-regulation has trivial positive correlation with achievement in science. But there is moderately higher positive correlation with learning goal orientation, task value and self-efficacy than self-regulation. Positive correlation indicates that the academic achievement depends on all the other variables. The correlation coefficients obtained are statistically significant as $p<0.01$. Academic achievement in Science is directly depending on all these factors. Students who set their goal and working hard to chase the goal will be keeping themselves motivated and become high achievers. They find importance in the tasks which are assigned to them and try to finish on time.

\section{Conclusion and Suggestions}

Many studies mentioned that students' beliefs deep on themselves are the causes behind the self-regulatory skills, and these beliefs judge their capability to succeed in a given task (Pajares; 2002). Students' motivational beliefs and self-regulatory practices have been identified as instrumental in influencing the engagement of students in their learning process (Velayutham et al; 2011, p. 2159). This study was attempted to find if a relationship exists between students' self-regulation and engagement in learning mathematics and science and their academic achievement. According to the statistics described in Table 5 and Table 9 shows that there is a positive correlation with learning goal orientation, task value, self-efficacy and self-regulation and the achievement in both mathematics and science. Students' task values are correlated with deep learning strategies (elaboration, organisation, etc.) and academic achievement (Pintrich \& Schunk, 2002). De Backer and Nelson (1999) state that there are direct correlations between task value and learners' achievement goals. Pintrich et al. (1991) say that self-regulated students can manage both their time and study environment, and that they can regulate them. This research found that learning goal orientation, task value, self-efficacy and self-regulation has direct effects on the achievement in both mathematics and science. The variable with the greatest effect was learning goal orientation with self-efficacy, followed by self-regulation in both Mathematics and science. This shows that academic achievement is not only depending on cognitive factors but also on other noncognitive factors such as learning goal orientation, self-efficacy, self-regulation and many other similar factors. Students' self-regulatory skills should be developed in order to advance in achievement. Most successful students in school apply their self-regulated learning skills more than those who are not successful. Self- regulated learners relate and assess their own learning outcomes. Students who take on the responsibility of their own learning in this way can examine each stage of their learning and thus can attain success at the desired level. It is evident in this study that students' academic achievement significantly depends on learning goal orientation and self-efficacy.

This study finding has some important implications for authorities of education. I think these results could have a positive influence if considered while teaching mathematics and science to students. It was found that the motivational variables such as task value, goal orientations self-efficacy and self-regulation had direct and indirect effects. Therefore, teachers should motivate students in the classroom in order to raise their achievement. It is the motivational factor that leads to self-regulation of students. It is important to take measures to increase personal interest in subjects such as Mathematics and Science and help them to keep up that interest. This will intern help the 
students to get rid of their test anxieties or limit to a minimum. Teachers can provide opportunities to control their learning day by day and help them to attain success at the desired level. This will be a supporting factor for the efforts of the government on development of teaching and learning activities at schools. Developed gulf countries like Bahrain made huge investments towards the development of education sector. As part of enhancing the quality of teaching and learning, the ministry of education in Bahrain implemented many projects especially in mathematics. This study can help them in integrating the above mentioned non-cognitive factors in future curriculum development. In conclusion, in order to understand how students become active managers for their own learning there are various factors such as their self-regulation, learning goal orientation, self-efficacy and the academic activities or type of engagements .

Mathematics and science are the important subjects to achieve the $21^{\text {st }}$ century skills. This put more pressure on these subject teachers and curriculum developers to find ways to teach in creative ways and use examples that are practical and familiar to students instead of solving abstract problems which can cause anxiety and failure to understand the concepts and result in low performance. As per the questionnaire analysis, most students assess science and mathematics as boring and difficult subjects. Hence teachers should make the students feel interested in these subjects, to build a good attitude towards them. Finally more research should be done on how the cognitive and noncognitive factors can affect math and science performance and to improve these subjects' outcomes in the country. In this study the academic achievement was analyzed based only on students' midterm exam results. Different variables can also be considered using various data collection tools for academic achievement in future researches.

\section{Disclosure statement}

No potential conflict of interest was reported by the authors.

\section{Notes on Contributors}

Masooma Ali Al Mutawah - University of Bahrain, Kingdom of Bahrain.

Ruby Thomas - University of Bahrain, Kingdom of Bahrain.

Myint Swe Khine - Emirates College for Advanced Education, United Arab Emirates.

\section{References}

Bandura, A. (1997). Self-efficacy: The exercise of control. New York: Freeman.

Baumeister, R. F. \& Vohs, K. D. (2004). Handbook of self-regulation: Research, theory, and applications. New York, NY: Guilford Press.

Becker, D. R., McClelland, M. M., Loprinzi, P., \& Trost, S. G. (2014). Physical activity, selfregulation, and early academic achievement in preschool children. Early Education \& Development, 25, 56-70. doi: 10.1080/10409289.2013.780505.

Bembenutty, H., \& Zimmerman, B. J. (2003, April). The relation of motivational beliefs and selfregulatory processes to homework completion and academic achievement. Paper presented at the Annual Meeting of the American Educational Research Association, Chicago, IL. 
BernierClarebout, G., Horz, H., \& Schnotz, W. (2010). The relations between self-regulation and the embedding of support in learning environments. Educational Technology Research and Development, 58 (5), 573-587.

Boekaerts, M. (1996). Self-regulated learning at the junction of cognition and motivation. European Psychologist, 1, 100-112.

Boekaerts, M., \& Corno, L. (2005) Self-regulation in the classroom: A perspective on assessment and intervention. Applied Psychology: An International Review, 54(2), 199-231.

Bull, R. \& Scerif, G. (2001) Executive functioning as a predictor of children's mathematics ability: inhibition, switching, and working memory. Developmental Neuropsychology, 19, 273-293.

Butler, D. L., \& Winne, P.H. (1995). Feedback and self-regulated learning: A theoretical synthesis. Review of Educational Research, 65(3), 245-281.

Canca, D. (2005). Cinsiyete gore universite oğrencilerinin kullandıklarıbilişsel ve bilişustu oğrenme stratejileri ve akademik başarıları arasındaki ilişkilerin incelenmesi. Yayınlanmamış yüksek lisans tezi, Yıldız Teknik Üniversitesi, Sosyal Bilimler Enstitüsü, İstanbul.

Cantwell, R. H. (1998). The development of beliefs about learning from mid- to late adolescence. Educational Psychology, 18(1), 27-40.

Corno, L. (2001). Volitional aspects of self-regulated learning. In B. J. Zimmerman \& D. H. Schunk (Eds.), Self-regulated learning and academic achievement: Theoretical perspectives (2nd ed., pp. 191-226). Mahwah, NJ: Lawrence Erlbaum Associates.

Crawford, K., Gordon, S., Nicholas, J., \& Prosser, M. (1998). University mathematics students' conceptions of mathematics. Studies in Higher Education, 23, 87-94.

Davis, D. (2011). Non-Cognitive Constructs and Self-Reported Creativity by Domain. Journal of Creative Behavior, Volume 45 Number 3 Third Quarter 2011, 188-198.

De Backer, T. K., \& Nelson, R. M. (1999). Variations on an expectancy-value model of motivation in science. Contemporary Educational Psychology, 24, 71-94.

De Bruin, A.B., Thiede, K.W., \& Camp, G. (2011). Generating keywords improves metacomprehension and self-regulation in elementary and middle school children. Journal of Experimental Child Psychology, 109 (3), 294-310.

De Corte, E., Mason, L., Schraw, G., Crippen, K., \& Hartley, K. (2006). Pro-moting self-regulation in science education: metacog-nition as part of a broader perspective on learning. Research in Science Education, 36, 111-139.

De Corte, E., Op’t Eynde, P., \& Verschaffel, L. (2002). -Knowing what to believe: Therelevance of students' mathematical beliefs for mathematics education. In B. K. Hofer \& P. R. Pintrich (Eds.), Personal epistemology: The psychology of beliefs about knowledge and knowing (pp. 297-320).

De corte, E., Verschaffel, L., \& Op'teynde, P. (2000). Selfregulation: A characteristic goal of mathematics education. In M. Boekaerts, P. R. Pintrich, \& M. Zeidner (Eds.), Handbook of self-regulation: Theory, research, and applications (pp. 687-722). San Diego, CA: Academic Press.

Deci, E. L., \& Ryan, R. M. (2002). Handbook of self determination research. Rochester, NY: University of Rochester Press.

Eilam B., Zeidner M. and Aharon, I. (2009) Student conscientiousness, self-regulated learning, and science achievement: an explorative field study. Psychology in the Schools, 46 (5), $420-432$. www.interscience.wiley.com. DOI: 10.1002/pits.20387.

Eom, Y., \& Reiser, R. A. (2000). The effects of self regulation and instructional control on performance and motivation in computer-based instruction. International Journal of Instructional Media, 27(3), 247-261.

Ergöz, G. (2008). Investigation of self-regulated learning and motivational beliefs mathematics achievement Yayınlanmamış yüksek lisans tezi, Middle East Technical University, Department of Secondary Science and Mathematics Education, Ankara. 
Eshel, Y., \& Kohavi, R. (2003). Perceived classroom control, self-regulated learning strategies, and academic achievement. Educational Psychology, 23, 249-260.

Forgas, J. P., Baumeister, R. F., \& Tice D. M. (2009). Psychology of self-regulation. Cognitive, affective and motivational processes. New York: Psychology Press Tylor \& Francis Group.

Fox, K. R., \& Wilson, P. M. (2008).Self-perceptual systems and physical activity. In T.S. Horn (Ed.), Advances in sport psychology (pp. 49-64). Champaign, IL: Human Kinetics.

Garavalia, L. S., \& Gredler, M. E. (2002). An exploratory study of academic goal setting, achievement calibration and selfregulated learning. Journal of Instructional Psychology, 29 (4), 221-230.

Glaser, C., \& Brunstein, J. C. (2007). Improving fourth-grade students' composition skills: Effects of strategy instruction and self-regulation procedures. Journal of Educational Psychology, 99 (2), 297-310

Gollwitzer, P. M., \& Brandstätter, V. (1997). Implementation intentions and effective goal pursuit. Journal of Personality and Social Psychology, 73(1), 186-199.

Grouws, D. A., Howald, C. L., \& Colangelo, N. (1996, April). Student conceptions of mathematics: A comparison of mathematically talented students and typical high school algebra students. Paper presented at the American Educational Research Association, New York, NY.

Hannula M., Evans J., Philippou, G., and Zan R. (2004) Affect in mathematics education - exploring theoretical frameworks. Proceedings of the 28th Conference of the International Group for the Psychology of Mathematics Education, 1, 107-136.

Harris, K. \& Graham, S. (1999). Programmatic inter-vention research: Illustrations from the evolution of self-regulated strategy development. Learning Disabil-ity Quarterly, 22, 251262 .

Harris, K. R., Friedlander, B.D., Saddler, B., Frizzelle, R. \& Graham, S. (2005). Self monitoring of attention versus self-monitoring of academic performance: Effects among students with $\mathrm{ADHD}$ in the general education classroom. Journal of Special Education, 39 (3), 145-156

Haşlaman, T. (2005). Programlama dersi ile ilgili oz-duzenleyici oğrenme stratejileri ve başarı arasındaki ilişkilerin incelenmesi: Bir yapısal eşitlik modeli. Yayınlanmamış yüksek lisans tezi, Hacettepe Üniversitesi, Fen Bilimleri Enstitüsü, Ankara.

Hofer, S.M.(1999. Assessing personality structure using factorial invariance procedure, in I.Mervielde, I.J. Deary, F. De Fruyt and F. Osterndof (eds) Personality Psychology in Europe, vol. 7, pp. 35-49. Tilburg, Netherlands: Tilburg University Press.

Iran-Nejad, A. (1990). Active and dynamic self regulation of learning processes. Review of Educational Research, 60, 573-602.

Kenney, P. A., \& Silver, E. A. (Eds.). (1997, November). Results from the sixth mathematics assessment of the National Assessment of Educational Progress.

Kinney, D. P. (2001). Developmental theory: Application in a developmental mathematics program. Journal of Developmental Education, 25(2), 10-12, 14, 16,18, 34.

Kitsansas, A., Sten, S., \& Huie, F. (2009). The role of selfregulated strategies and goal orientation in predicting achievement of elementary school children. International Electronic Journal of Elementary Education, 2 (1), 65-81.

Koller, O. (2001). Mathematical world views and achievement in advanced mathematics in Germany: Findings from TIMSS population 3. Studies in Educational Evaluation, 27, 65-78.

Kolovelonis, A., Goudas, M., \& Dermitzaki, I. (2011). The effect of different goals and self-recording on self-regulation of learning a motor skill in a physical education setting. Learning and Instruction, 21 (3), 355-364.

Kuhl, J., \& Fuhrmann, A. (1998). Decomposing self-regulation and self-control: The volitional components inventory. In J. H. C. S. Dweck (Ed.), Motivation and self-regulation across the life span (pp. 15-49). Cambridge: Cambridge University Press. 
Labuhn, A.S., Zimmerman, B.J., \& Hasselhorn, M. (2010). Enhancing students' self regulation and mathematics performance: The influence of feedback and self evaluative standards Metacognition and Learning, 5 (2), 173-194.

Lampert, M. (1990). When the problem is not the question and the solution is not the answer: Mathematical knowing and teaching. American Educational Research Journal, 27, 29-63.

Leininger, L. J. and Khalil, A. (2008) Cognitive and Non-Cognitive Predictors of Success in AEP. Journal of Policy Analysis and Management, 27(3), 521-535. DOi: 10.1002/pam.20357.

Mahwah, NJ: Erlbaum Muis, K. R. (2004). Personal epistemology and mathematics: A critical review and synthesis of research. Review of Educational Research, 74, 317-377.

McClelland, M. M., Cameron Ponitz, C. E., Connor, C. M., Farris, C. L., Jewkes, A. M., \& Morrison, F. J. (2007). Links between behavioral regulation and preschoolers' literacy, vocabulary, and math skills. Developmental Psychology, 43, 947-959. doi:10.1037/0012-1649.43.4.947.

McClellan, E. (1999). Moral education in America: Schools and the shaping of character from colonial times to the present.New York, NY: Teachers College Press.

Moffitt, T. E., Arseneault, L., Belsky, D., Dickson, N., Hancox, R. J., Harrington, H., Houts, R., Poulton, R., Roberts, B.W., Ross, S.,Sears, M. R., Thomson, W. M. \& Caspi, A. (2011) A gradient of childhood self-control predicts health, wealth, and public safety. Proceedings of the National Academy of Sciences of the United States of America, 108, 2693-2698.

Nicholls, J. G. (1989). The competitive ethos and democratic education. Cambridge, MA: Harvard University Press.

Nota, L., Soresi, S., \& Zimmerman, B. J. (2004). Self-regulation and academic achievement and resilience: A longitudinal study. International Journal of Educational Research, 41(3), 198215

Pajares, F. (2002) Gender and Perceived Self-Efficacy in Self-Regulated Learning, Theory Into Practice, 41(2), 116-125. http://dx.doi.org/10.1207/s15430421tip4102_8.

Pape, S. J., \& Smith, C. (2002). Self-regulating mathematics skills. Theory into Practice, 41, 93-101.

Paulsen, M. B., \& Feldman, K. A. (2007). The conditional and interaction effects of epistemological beliefs on the self-regulated learning of college students: Cognitive and behavioral strategies. Research in Higher Education, 48, 353-401.

Pintrich, P. R. (2000). The role of goal orientation in self-regulated learning. In M. Boekaerts, P. Pintrich, \& M. Zeidner (Eds.), Handbook of self-regulation (pp. 451-502). San Diego, CA: Academic Press.

Pintrich, P. R., \& Schunk, D. H. (2002). Motivation in education: Theory, research, and applications. Columbus, OH: Merrill.

Pintrich, P. R., \& De Groot, E. (1990). Motivational and self-regulated learning components of classroom academic performance. Journal of Educational Psychology, 82(1), 33-50.

Pintrich, P., R., Smith, D. A. F., Garcia, T., \& McKeachie, W. J. (1991). A manual for the use of the motivated strategies for learning questionnaire (MSLQ). National Center for Research to Improve Postsecondary Teaching and Learning, Ann Arbor: Michigan, ED 338122.

Pokay, P., \& Blumenfeld, P. C. (1990). Predicting achievement early and late in the semester: The role of motivation and use of learning strategies. Journal of Educational Psychology, 82, 4150 .

Ruban, L., \& Reis, S. M. (2006). Patterns of self-regulatory strategy use among low-achieving and high achievming university students, Roeper Review, 28 (3), 148-156.

Schmeichel, B.J.; Baumeister. (2006) Self-regulatory processes defend against the threat of death: Effects of self-control depletion and trait self-control on thoughts and fears of dying. Journal of Personality and Social Psychology, 91(1), 49-62.

Schoenfeld, Alan H.(1992). "Learning to think mathematically: Problem solving, metacognition, and sense making in mathematics." Handbook of research on mathematics teaching and learning: 334-370. 
Schoenfeld, A. H. (1987). What's all the fuss about metacognition? In A. H. Schoenfeld (Ed.), Cognitive science and mathematics education (pp. 189-215). Hillsdale, NJ:Lawrence Erlbaum Associates.

Schoenfeld, A. H. (1989). Explorations of students' mathematical beliefs and behavior. Journal for Research in Mathematics Education, 20,338-355.

Schommer-Aikins, M., Duell, O. K., \& Hutter, R. (2005). Epistemological beliefs, mathematical problem-solving beliefs, and academic performance of middle school students. The Elementary School Journal, 105, 289-304.

Schunk, D. H. (1986). Verbalization and children's self-regulated learning. Contemporary Educational Psychology, 11, 347-369.

Schunk, D. H. (1996). Goal and self-evaluative influences during children's cognitive skill learning. American Educational Research Journal, 33, 359-382.

Seider, S. and Soutter, M. (2013) College Access, Student Success, and the New Character Education. Journal of College \& Character, 14(4), 351-356. doi:10.1515/jcc-2013-0044.

Schunk, D. H. (2000). Coming to terms with motivational constructs. Contemporary Educational Psychology, 25, 116-119.

Shunk, D. (1996). Goal and self-evaluative influences during children's cognitive skill learning. American Educational Research Journal, 33, 359-382.

Schunk, D. H. (1995). Self-efficacy and education and instruction. In J. E. Maddux (Ed.), Selfefficacy, adaptation, and adjustment: Theory, research, and application(pp. 281-303). New York: Plenum Press.

Sparkman, L., Maulding, W. S. and Roberts, J. G. (2002) Non-cognitive predictors of student success in college. College Student Journal, 642-652.

Strayhorn, T. (2015) Factors Influencing Black Males' Preparation for College and Success in STEM Majors: A Mixed Methods Study. The Western Journal of Black Studies, 39(1), 45-63.

Trainin, G., \& Swanson, H. L. (2005). Cognition, metacognition, and achievement of college students with learning disabilities. Learning Disability Quarterly, 28(4), 261-272.

Uredi, I. ve Uredi, L. (2005). İlkoğretim 8. sinıfoğrencilerinin oz- duzenleme stratejileri ve motivasyonel inanclarının matematik başarısını yordama gucu. MersinÜniversitesi Eğitim Fakültesi Dergisi, 1(2), 250-260.

Valiente, C., Lemery-Chalfant, K., Swanson, J. \& Reiser, M. (2008) Prediction of children's academic competence from their effortful control, relationships, and classroom participation. Journal of Educational Psychology, 100, 67-77.

Velayutham S., Aldridge S. J., and Fraser B. (2011) Development and Validation of an Instrument to Measure Students' Motivation and Self Regulation in Science Learning. International $\begin{array}{lllll}\text { Journal of Science } & \text { Education, } & 33(15), & 2159 & -\end{array}$ http://dx.doi.org/10.1080/09500693.2010.541529.

Velayutham S., Aldridge S. J., and Fraser B. (2012) Gender differences in student motivation and self-regulation in science learning: a multi-group structural equation modeling analysis. International journal of science and mathematics education, 10, 1347-1368.

Winne, P. H. (2000). Information processing models of self-regulated learning. In B. J. Zimmerman \& D. H. Schunk (Eds.), Self-regulated learning and academic achievement: Theory, research, and practice. New York: Longman.

Wolters, C.A. (2011). Regulation of motivation: Contextual and social aspects. Teachers College Record, 113 (2), 265-283.

Zhou, Q., Main, A. \& Wang, Y. (2010) The relations of temperamental effortful control and anger/frustration to Chinese children's academic achievement and social adjustment: a longitudinal study. Journal of Educational Psychology, 102, 180-196.

Zimmerman, B. J. (1995). Self-efficacy and educational development. In A. Bandura (Ed.), Selfefficacy in changing societies (pp. 202-231). New York: Cambridge University Press. 
Zimmerman, B. J. (2006). Development and adaptation of expertise: The role of self-regulatory processes and beliefs. In K. A. Ericsson, N. Charness,P. J. Feltovich \& R. R. Hoffman (Eds.), The Cambridge handbook of expertise and expert performance (pp. 705-722). New York, NY: Cambridge University Press.

Zimmerman, B. J., \& Kitsantas, A. (2005). Homework practices and academic achievement: The mediating role of self-efficacy and perceived responsibility beliefs. Contemporary Educational Psychology, 30, 397-417.

Zimmerman, B. J. (2002) Becoming a Self-Regulated Learner: An Overview. Theory Into Practice, 41(2), 64-70. http://dx.doi.org/10.1207/s15430421tip4102_2.

Zimmerman, B. (2000). Attaining self-regulated learning: A social-cognitive perspective. In M. Boekaerts, P. Pintrich, \& M. Zeidner (Eds.), Handbook of self-regulation (pp. 13-39). San Diego, CA: Academic Press.

Zimmerman, B. J., Bandura, A., \& Martinez-Pons, M. (1992). Self-motivation for academic attainment: The role of self-efficacy beliefs and personal goals setting. American Educational Research Journal, 29, 663-676.

Zimmerman, B. J., \& Bandura, A. (1994). Impact of self-regulatory influences on writing course attainment. American Educational Research Journal, 31, 845-862.

Zimmerman, B. J. (1998). Developing self-fulfilling cycles of cademic regulation: An analysis of exemplary instructional models . In D. H. Schunk \& B. J. Zimmerman (Eds.), Self-regulated learning: From teaching to self-reflective practice (pp. 1-19).

Zimmerman, B. J., \& Martinez-Pons, M. (1988). Construct validation of a strategy model of student self-regulated learning. Journal of Educational Psychology, 80(3), 284-290.

Zimmerman, B. J., \& Martinez-Pons, M. (1986). Development of a structured interview for assessing student use of self-regulated learning strategies. American Educational Research Journal, $23,614-628$

Zusho, A., Pintrich, P. R., \& Coppola, B. (2003). Skill and will: The role of motivation and cognition in the learning of college chemistry. International Journal of Science Education, 25 (9), 10811094 . 